\title{
Classical tradition and Judeo-Christian revelation in Clement of Alexandria
}

Claudio Calabrese - Nassim Bravo

(Panamerican University, México)

\begin{abstract}
Clement of Alexandria is one of the most iconic intellectuals of primitive Christianity. His attitude towards Classical Greek culture had a decisive role in its acceptance as an appropriate instrument for the interpretation of biblical revelation. In the context of the present article, we follow the Clementine account of the Orphic texts, an interpretation distinguished by its manner of tackling the issue. This meant not only that he ignored the context in which the "Orphic tradition" developed, but also that he set aside the immanent quality of Greek culture. Clement's approach would have a deep impact on the way in which Late Antiquity Christianity would understand divine nature and the limits of the act of faith.
\end{abstract}

\section{Keywords}

Clement of Alexandria; Hellenistic culture; Orphism; Late Antiquity; primitive Christianity 


\section{Introduction}

In the present article we would like to discuss the formation of Christian philosophy focusing on the integration of Greek culture as a resource to interpret revelation. It is within this context that we approach the manner in which Clement of Alexandria incorporated texts from Orphic tradition into his Stromata $V$; we are alluding here to a group of quotations, including a few comments and references to the Old Testament, particularly to the Book of Isaiah, used by Clement as an argument to help us understand God. The interpretation of the revealed fact is a complex intellectual process that involves, on the one hand, an analysis of the universe of each textual corpus - Greek and Old Testament - and, on the other hand, the acceptance of the Christian view of the one who is collecting the texts and expressing his desire to understand by taking into account Hellenic culture.

Although the texts quoted belong to the "Orphic tradition," we shall not stop on that complex question or attempt to identify its intrinsic meaning. We do not deal with that, as Clement of Alexandria accepted these texts uncritically and used them with complete disregard of its context, i.e., he overlooked the facts of the problem. ${ }^{1}$ His interpretation is determined by this attitude, as the mindset of the Alexandrian has little to do with that of the skeptic intellectual worried about the meticulousness of the method. Indeed, he does not take into account the profound differences between both worldviews, but interprets according to what he understands as God's providential design: an essential continuity between revelation and the cultures he is discussing. Thus, we would like to underscore that it is not our goal to show the historical significance of Orphism. By "Orphic" we understand "those who followed the religious teachings in the works or rites attributed to Orpheus; they are a very heterogeneous group, which ought to be included in the Dionysiac circles, insofar as the Orphic mysteries are also Bacchic mysteries." 2 Clement transformed these teachings into an instrument for the better understanding of God. A good part of the Christian philosophy and theology rose from this conviction, creating a path out of new intuitions on the mystery of salvation.

The theologians from the second century used - and this was one of their most important contributions - the concept of God as the main content of revelation, and tried to consolidate it by using metaphysics. This might sound simple, but the process was tempestuous: the attempt of enriching the understanding of the God of the Scriptures by using concepts was the cause of profound rejection, as it was claimed that philosophy had the role of a disturbing rationalism. The task was accomplished against a polemical background: the justification of the Christian novelty towards the pagans, who claimed the believers of the new religion were atheists. This process unfolded within the cultural context of the Jewish tradition of interpreting the Bible, the apocalypticism of which determined in a decisive manner the doctrinal orientation of primitive Christianity.

1 This method of appropriation, although applied to Platonic tradition, has been extensively studied by Wyrwa (1983).

2 Bernabé (2011: pp. 11-12); Bernabé et al. (2010); Pérez (2011: pp. 113-131). The autor discusses the context of the Orphic passages. 
It is important to make here a methodological note. The notion of "God's transcendence" has to be explained in its limits and continuity with the Hellenistic culture. Indeed, the idea of a transcendent divinity as understood in Judeo-Christian tradition was foreign to the Greco-Roman world. The latter's interpretation was so immanently connected to the notion of physis ${ }^{3}$ (the totality and rule of everything that exists in an ontological and ethical sense) that the divine could not be understood outside of it; the "degrees of divinity" and the "degrees of intelligibility" corresponded to each other so much that they became synonyms. Modern interest in Orphic tradition stems from the perceived similarities with Christianity; they apparently have some elements in common, notwithstanding their asymmetric relation to each other, and they have become appealing because of the contrast they present with the more conventional Greek religiosity. The elements we might consider as common (the survival of the soul after death and its reward or punishment in the afterworld) show, as we will discuss later, a double adaptation to the Greek concept of physis and to the transcendent life characteristic of Christianity. ${ }^{4}$

What does transcendence mean in each case? Orphic tradition interpreted transcendence in spatial terms as a "here" and a "beyond" that is available at all times. Christian faith understood it in a temporal sense as an "unlimited present" and a "succession of instants," an acting by God that cannot dissolve into metaphysical considerations, i.e., something that is never "at the disposal of man." The salvific message of Christ is conceived in a temporal key and interpreted as a comprehensible, albeit supernatural, truth for man. ${ }^{5}$

Our methodological approach is hermeneutical, inasmuch as our goal is to recover the vitality of the letter and the universe it represents. If every culture involves an interpretation, the cultural consideration contains an expositive reflection about the tradition to which it belongs and, in a fundamental manner, the life it expresses. ${ }^{6}$

\section{The Theoretical Presuppositions and the Interpretation Model in Stromata $V$}

A generation before Origen, that is, around the year 159, Clement of Alexandria was born, presumably in Athens. It is also believed that he studied in the city connected to his name, both in public and Christian schools, a fact that would explain his vast knowledge of Greek literature and philosophy. ${ }^{7}$ Our interest in this versatile and contradictory

3 As a rule, we transliterate the Greek technical terms. However, we transcribe in Greek characters the most significant terms in the quotations by Clement.

4 Herrero de Jáuregui (2010: pp. 2-4).

5 Grabmann (1957: p. 62).

6 We associate this with the following idea by Ricoeur: "The reader here is every time a confessing community that understands itself by interpreting the texts that constitute the base of its identity." Ricoeur (2008: p. 194).

7 Cf. Hägg (2006: pp. 51-70). 
writer $^{8}$ stems from his use of the hermeneutical models of Hellenism in order to understand in a more profound manner the text of the revelation, but without attempting to reject or refute the Greek myths. ${ }^{9}$ The Alexandrian appropriates the Greek material with the clear intention of erecting the new building we have called "Christian philosophy." 10

The conception of this new world presented an issue with which Clement ${ }^{11}$ himself was familiar: how to establish a hierarchy in the various forms of knowledge. From a theoretical point of view, it was a matter of finding a principle of unity between the various moments of speculation. This intense debate also occurred within the Greco-Roman culture, particularly among the Stoics, who focused on the ethical question and wondered how to organize the rest of philosophy, especially physics. ${ }^{12}$ Lucius A. Seneca (Epistulae ad Lucilium, 94 and 95) also mentioned the principles of theoretical philosophy, especially those represented in physics, ${ }^{13}$ before dealing with ethics and its practical development, when following the distinction posed by Eudorus of Alexandria ( $f$. 25 a.C.) and, in a more explicit way, by Posidonius (135-151 a.C.). When this scheme is applied to the Stromata, we find a new outline; there philosophy is reduced to its discursive concretion, for Christianity is presented as the true philosophy (the only valid knowledge and way of life). This "true philosophy" appropriates the Neoplatonic wisdom, which would transform, after Clement and Origen, into an instrument of theological knowledge.

In Stromata V, Clement returns to the question about faith after having introduced the perfect gnostic, that is, the martyr, in the last chapters of Stromata IV. It is in the context of the polemic against Valentinus and Marcion that the Alexandrian claims that gnosis and faith need each other in the same way as the Father and the Son cannot be understood in an independent manner: faith leads to gnosis. ${ }^{14}$ Therefore, true gnosis is an ap-

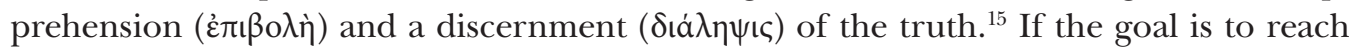
the truth (the Father) through the truth (the Son), the knowledge of the Unknown ${ }^{16}$ requires one to believe in the unknown. Thus, true gnosis is total contemplation ( $\theta \varepsilon$ coía). As intuitive knowledge, $\theta \varepsilon$ co ia is different from discursive knowledge, even though they tend to become one. As the foundation of discursive knowledge, intuitive knowledge can

$8 \quad$ Klibengajtis (2004: pp. 316-331).

9 Dawson (1992: pp. 199-205).

10 Merino (2008: p. 810).

11 Cf. Clement of Alexandria, Stromata, I, 28-32. Cf. Van den Hoek (1988: pp. 23-47).

12 Merino (2008: pp. 810-811).

13 Ibid. (p. 811).

14 Clement of Alexandria, Stromata, V, 1, 4. Hägg (2012: p. 137): "In Clement these two ways to the knowledge of God, through religious practice and theological reflection, are closely related. He seems to emphasize the mystical, supra-rational aspect in man's relationship with God more than had been common so far in the history of the Church. In this he proved highly influential to the later, especially Eastern, tradition. (...) Clement therefore distinguished between the unknown Father and the revealed Logos, the dynamis of God: God remains unknown, but the Son, Logos, or dynamis, has revealed him to men."

15 Ibid. These are terms of Epicurean epistemology. In his Letter to Menoeceus (123-124), Epicurus uses the term $\dot{\varepsilon} \pi \_\beta \lambda_{\eta}$ to indicate in a brief and simple way the comprehension of the "scheme of the whole doctrine.” Cf. Arrighetti (1960). Cf. Asmis (1999: pp. 260-294); Aoiz (2012: pp. 165-179). 
occur independently, since it expresses the primacy of intelligent intuition over rational discourse. ${ }^{17}$

For this reason, faith is the ear of the soul, for the one who has believed, understands (to listen as a way of understanding). Clement refers to Mathew 11, 15 and to Homer (Od., VI, 185). ${ }^{18}$ According to this listening capacity of the soul, and to the obedience/ disobedience that derives from it, we see that faith is susceptible to augmentation or reduction. In this he disagrees with Basilides, who claimed that the chosen knows God by virtue of nature ( $\varphi$ v́øı) $)^{19}$ the Gnostic thinks that the intelligence is closer to faith and to the creation of the good, because he understands faith as an essence (ovoía), not as a possibility.

To the Alexandrian, understanding faith as "power" ( $\dot{\varepsilon} \xi_{\text {ov }}$ ía), i.e., as the "faculty or freedom to do something" (the most significant reference to this is in Plato, Gorgias 461 e, and Laws 936 a) involves an idea of faith not only as an unsurpassable creation,

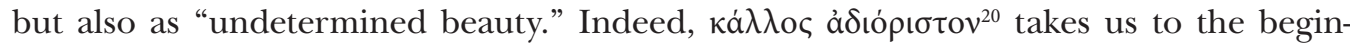
ning of speculative theology, as it tries to understand Biblical revelation in the context of Hellenistic culture and, for this very reason, attempts to include philosophy and the mythical-literary universe in a systematic way. Ká $\lambda \lambda$ os has here a meaning of totality stemming from a clear awareness of Biblical tradition and of the esthetic dimension. Within this context, we see that Clement takes up the task of tackling an earnest issue: can the Hellenistic esthetics be at the service of a deeper understanding of the Christian message? Is it possible to have a dialogue between the ethical-religious and the esthetic, understanding the beautiful as the very original nature of the world? This definition of faith, originally Gnostic, coexists with other definitions by the Alexandrian, but in this case it gets us closer to a way of describing the experience of believing. In other cases, in the same Strom. (V, 3, 2, for example), faith is understood as freedom to ascent. However, the "undetermined beauty," when separated completely from its Gnostic content, opens up a path of multiple consequences in the development of Christian theology. The difficulty of these questions reside more within ourselves than in Clement's texts. When the very notion of nature is in crisis, how is it possible to present the common root of the ethical and the esthetical? What we call beauty is as contaminated by irreality as the enlightened concept of reason. Only if we are able to unfold the Logos that creates the beauty in Cosmos we open the road to the original beauty of the love of God. In order to adapt these claims to Clement's historical and cultural moment, we should take into account the fact that, to him, the Bible was the oldest document and, in consequence, the most pure, to express the root of all poetry.

17 Sciacca (1970: p. 33).

18 For us the peculiarity of the Homeric passage is the following: after leaving Ogygia, Odysseus arrives at the island of the Phaeacians. He hides in the woods, near a river. The next morning, he meets Nausicaa and her maidens, to whom he asks to stay away, because he wants to approach the river in order to remove the dirt from his body, after so many days of sea voyage and shipwrecks. At this point (VI, 185), Homer closes the passage: "and they listened to him (éklyon) perfectly."

19 Clement of Alexandria, Stromata, V, 3, 1.

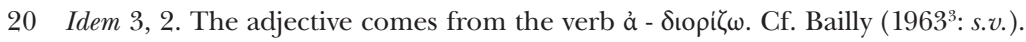


"Even when the cause of investigating every question is removed, faith remains firm..."21 We understand the quoted passage in the following way: faith is not defined as a postulate of reason, as there is no human measure that is acceptable for the divine: reason does not demand grace in the strict sense; rather, it is the latter that puts the former in tension towards God. If we consider the elements characteristic of the act of faith in terms of theological perception, we open up a path that involves philosophy and theology in a reciprocal manner, and then myth and revelation. Although faith remains firm within the believer insofar as he or she believes, faith is identified with bearing witness to God. Otherwise, how could a demonstration that does not lead us to the threshold of God be definitive? If life somehow begins with grace, faith constitutes in a sense a vision of the being of God: it sustains every creature inasmuch as it establishes the ways in which God meets us through sensitive perception and thought, because the profundity of God does not reside in verbal assertions, but in the unity of the Son that bears witness to the Father.

"Thus, we claim that it is not adequate that faith advances in a lonely and idle manner,

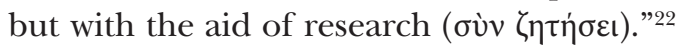

Clement understands this claim as the "cleverness of the soul," ${ }^{23}$ i.e., the more decisive attitude adopted by the believer who recreates his or her faith spiritually: an essential concern about circumscribing the divinity of God. Investigation is necessary in order to evaluate the relation between these factors. ${ }^{24}$ Such knowledge dictates the attitude of faith towards the Absolute: the authority of God's revealing Himself resides in the acknowledgement that the acts of culture are part of the providential character of God. In this sense, Clement thinks that the Orphic texts can "say something": the being is not a fact, but the expression of the objectivity of every entity. Therefore, the philosophical act is for the human a justification in which he or she stakes his or her whole existence. It is only from the intimacy of this choice that it is possible to reach the light of God that sustains the being. In this sense, the philosophical act leads to the threshold of faith, and to its acceptance or rejection (the supreme possibility of freedom as such occurs in the being). The next step, if there is one, leads the philosophical stage to its fulfilment, inasmuch as it represents the encounter with the being in terms of love; the anxiety for one's own fate transforms itself into an abandonment that is not concerned about its destiny. In other words, it is the reason thinking in the light of faith, a purifying force that helps reason be itself insofar as the former drives the latter, according to Romano Guardini, to spiritual and personal realities. ${ }^{25}$ How then can the knowledge of God occur? The question might be posed by taking into account the different levels of human understanding. The first level is the most universal and least clear, although it is accessible to everyone,

21 Idem $\mathrm{V}, 2,4$.

22 Clement of Alexandria, Stromata, V, 11, 1.

23 Ibidem.

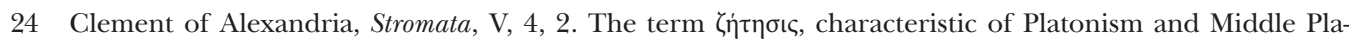
tonism, refers to scientific knowledge as opposed to vulgar knowledge, as we can see in Plato (Crat. 406 a; Tim. 47 a; Rep. 336 c and 368 c; Phaed. 66 d). 
and it appears in man in the moment of creation. For this reason Clement claims in Strom. VII, 8, 2 that the pagans were able to reach an obscure knowledge of God. It is certainly a very imperfect knowledge ( $\pi \rho$ ó $\lambda \eta \psi \iota \varsigma$ is the term used by the Alexandrian), but

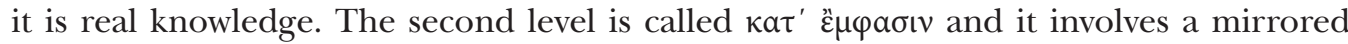
image, i.e., a knowledge that is reached by the soul understood as image, and, therefore, as reflection of God. The way to knowing God involves a strictly philosophical way, which is interpreted here as a gift from God. This doctrine, which would be heavily influential in the Patristic and Scholastic periods, appears for the first time in Clement. ${ }^{26}$

\section{Clement's Model of Interpretation}

Why Orpheus? As Herrero de Jáuregui suggests, one of the main motives behind this interest in Orphic tradition was the perception of its similarities with Christianity (although the scholar is alluding here to modernity, his claim might be applied to all ages). The distance that separates the Homeric religion from Orphism, and the seeming likeness between the latter and Christianity, has produced a not very nuanced image of theology and the social composition of Christianity. ${ }^{27}$ Nonetheless, both those who saw Orphism as a preparation for the reception of Christianity and those who considered it a manifestation of the decadence of the Classical spirit, they all agreed that Orphism was the preamble to Christianity in the Greek world. ${ }^{28}$ The elements they have in common express the confluence of several traditions, including Orphism and Christianity, in the spiritual koiné of the Mediterranean. ${ }^{29}$ For this reason, the Orphic texts attempt to explain the origin of the world, which was a concern present in the Hellenic culture in the mythical and philosophical realms. ${ }^{30}$ Both spheres remained apart until they found a common course in Plato and, to a lesser extent, in Aristotle. Plato refers to the theologoi as "divine men," i.e., inspired people to whom it was granted a knowledge greater than that of the plain mortals. We are aware of Plato's predicament or, more precisely, the predicament of Middle Platonism in the Patristic and specifically in Clement of Alexandria. Scattered in Plato's work we find multiple references to Orpheus, a figure closely linked to the origin, a feature that for the Greek mind was equivalent to "closer to the gods." ${ }_{11}$ This is the reason why we think Orpheus and the Orphic tradition were so highly esteemed by Clement.

26 Merino (2008: pp. 817-818).

27 Herrero de Jáuregui (2010: pp. 2-4).

28 Herrero de Jáuregui (2010: pp. 2-4).

29 Herrero de Jáuregui (2010: pp. 11-12).

30 Cf. Most (1999: pp. 332-362).

31 Some Platonic references: Crat. 402 b; Phil. 66 c; Leg. 669 d, 829 d; Rsp. 364 e, 715 e; Ion 536 b. From Aristotle: Met. 983 b 27 (the doctrine associated to Orphism in this passage to the one Plato also attributes to it in Crat. 402 b), 1000 a 9, 1071 b 27, 1091 a 34; Mund. 401 a 27. We take into account the insights by Alberto Bernabé (2011: pp. 22-24), who discusses what he calls the "Platonic reluctance" in relation to Orphism. 
We shall now see the Orphic quotations as Clement tries to coordinate the Hellenistic and Biblical texts that discuss God's unity, spirituality and inaccessibility (from a purely rational point of view). True to his style in Stromata, that is, uncritical towards the context, Clement quotes without further comment Xenophanes of Colophon in three different occasions: (a) God is not like the mortals in regard to the body ( $\delta \dot{\varepsilon} \mu a \varsigma)$ and the thought (vónua); ${ }^{32}$ (b) God cannot be represented in an anthropological fashion; ${ }^{33}$ (c) the fragment in which it is suggested that if horses, among other animals mentioned, had hands, they would draw figures of gods similar to horses. ${ }^{34}$ Then he quotes Bacchylides, who claims that those who are free of misery are no like mortal men. ${ }^{35} \mathrm{He}$ follows the Platonesque reinterpretation by the Stoic Cleanthes, whose concept of "the good" (Tảya $\theta$ òv $)^{36}$ is considered by Clement as equivalent to God.

In this context, the Alexandrian quotes the first passage of Orphic origin he has at his disposal:

"Oh, son of the great Zeus, father of Zeus the Aegis-Bearer!" ${ }^{77}$

When he considers Xenocrates of Chalcedon, who refers to a superior Zeus and to an-

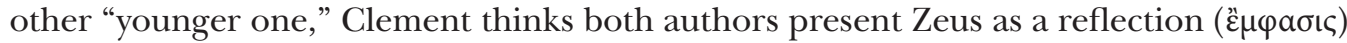
of the Father and the Son. ${ }^{38}$ The Alexandrian argues that these references, both from the Hellenistic culture, suggest that the intelligence alone cannot reach or understand the divine. ${ }^{39}$

As stated, the texts are put together in thematic groups, although it is difficult to establish the correspondence used in each case by the Alexandrian, as we are dealing with a compilation of non-interpreted references collected as a monumental mnemonic aid. However, the Biblical quotations allow an approximation. The text of Isaiah reads as follows:

“To whom then will ye liken God? Or what likeness will ye compare unto him?"40

"Not to an image made by the craftsman [...] or by a goldsmith that smelts gold to gilt it?" 41

32 Fr. 21 b 23 (Diels-Kranz) in Clement of Alexandria, Stromata, V, 109, 1.

33 Fr. 21 b 14 (Diels-Kranz) in Clement of Alexandria, Stromata, V, 109, 1.

34 Fr. 21 b 15 (Diels-Kranz) in Clement of Alexandria, Stromata, V, 109, 1.

35 Fr. 23 (Snell) in Clement of Alexandria, Stromata, V, 110, 1.

36 Fr. 557 (Kern) in Clement of Alexandria, Stromata, V, 110, 1.

37 Fr. 338 (Kern) in Clement of Alexandria, Stromata, V, 116, 1.

38 Clement of Alexandria, Stromata, V, 116, 1.

39 Clement of Alexandria, Stromata, V, 118, 3.

40 Is. $40,18$.

41 Is. 40,19 . 
The text by Isaiah concludes with the idea of an absolute transcendence, but how to interpret the aforementioned texts in the light of the Book of Isaiah? The notion of the

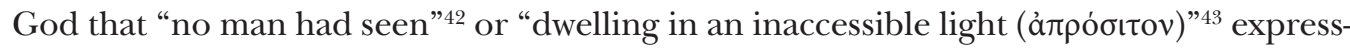
es a notion that is common to both Testaments: from his absolute transcendence, expressed in the aforementioned terms, he becomes visible, he becomes historical and can be transformed into an object of a creature's experience. This mode of revelation (God, who is beyond perception, comes into the world) suggests that the form - that through which he becomes manifest - makes it possible that the Father is revealed through the glory of the Son. The form presents the strongest link with the Classical world, for it was the characteristic space of the theophanic aspect of the gods. ${ }^{44}$ If we take into account Clement's anti-Gnostic position, his conviction that the creation is essentially revelation becomes decisive.

If the world is the space in which God presents himself, Christ is the culmination of this process, as he reveals everything that God is, or, in other words, he defines the faith of the Christian. This was valid both in the Old Testament world and the Greco-Roman world. We believe the Alexandrian tries to track this possibility in the Hellenic culture, with all the contradictions this path involves. For this reason, if we establish a correlation between the freedom of the human expressivity and the divine-human expressivity, it is possible at the same time to build a bridge between the theological content and the expressive forms of the myth that participate in the progressive character of revelation.

The interpretation of myth as an original moment of revelation constitutes one of Clement's most important contributions to the foundation of Christian theology. Indeed, this integration of the necessity of the mythical world and the freedom proper to creation suggests that revelation becomes comprehensible as a process: there is no randomness, only providential design.

There are three Orphic texts that allow us, in the light of Isaiah 66:1, to deepen the criteria presented by Clement thus far:

"When looking at the logos divine, engage with it diligently,

And drive the intellectual (vospòv) cavity of your heart.

Tread well on the path,

And behold the only king of the immortal world." ${ }^{45}$

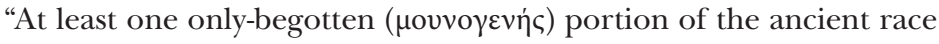

Of the Chaldean, for it was well versed in the astral march,

And in how around the Earth it performs

The movement of the sphere,

Spinning circularly around its own axis,

42 Jn. 1, 18.

431 Tm. 6, 16.

44 Cf. Otto (2003: pp. 72-75).

45 Fr. 246 (Kern) in Clement of Alexandria, Stromata, V, 123, 1. 
And [how] it leads the winds around air and sea." 46

"Indestructible, immortal, pronounceable ( $\dot{\eta}$ tòv) only to the immortals.

They see the greatest of the gods with powerful necessity,

Terrible, invincible, grand, immune, by the ether crowned." ${ }^{47}$

The text in Isaiah (66:1) says: "The heaven is my throne, and the earth is my footstool."

As stated before, the Alexandrian disregards the context of the Orphic verses and associates them to Isaiah, i.e., he overlooks their clearly Henotheistic (the reference to one religious Principle and to several immortals $)^{48}$ and immanent world view. The quoted Orpheus' verses come from different poems and have been selected with an unclear criterion. It is likely that the source was an anthology intended for school use or with apologetic purposes. We follow here the comment by Herrero (2007: p. 172) on the context of the quotation: "it is most likely that Clement ignored or thought it was marginal enough so he could change its meaning without disturbing his readers." ${ }^{49}$ The introductory comment is brief, but important, for it states that Orpheus mentions that

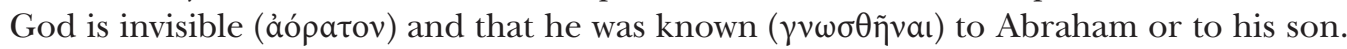

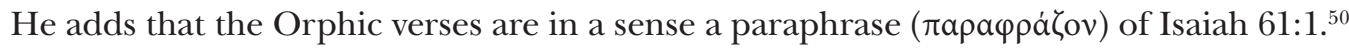
The Orphic turn aforementioned, "pronounceable only to the immortals," manifests an archetypical experience of the faith, for the story of salvation goes beyond the forms that express it: the Logos operates in the Orphic poetry and in the Scriptures.

It is against this background that the comprehension form of the Platonic esthetics, which is part of Clement's intellectual repertoire, comes into play, because the contemplation that comes from the intellectuality of the heart ("the intellectual cavity of your heart") leads to a $\theta$ copia that combines the distinctive Orphic mystic and the transcendence of the Judeo-Christian God. Clement interprets this in the following manner: Isaiah shows a material picture of God's transcendence, which is strengthened by a worldly esthetic, the sensitive beauty as the highest way of expressing God. The Alexandrian spiritualizes this perception even more, although he uses materialized images, as he thinks that between the two spheres (Orpheus and Isaiah) there is a certain analogy, not an identity, which springs from actuality. This leads to a second stage in Clement's interpretation. If we consider the comprehension of God in the Old Testament from an eschatological point of view, this can also be applied to the process of revelation. It is clear, therefore, that his goal is not to analyze the meaning of the verses, but to underscore the continuity between the two traditions. We might associate this attitude with the Alexandrian's apologetic urgency, as he was still heavily influenced by the necessity

46 Fr. 246 (Kern) in Clement of Alexandria, Stromata, V, 123, 2.

47 Fr. 248 (Kern) in Clement of Alexandria, Stromata, V, 125, 1.

48 This principle is often called Zeus as a way of alluding to its preeminence, although there is no direct relation to the Olympic god. Cf. Mendoza (2011: p. 29): "A Rise of Zeus to First Principle and Sovereign of the universe cannot be made directly, but rather requires a re-examination of established mythology."

49 Herrero de Jáuregui (2007: p. 172).

50 Fr. 248 (Kern) in Clement of Alexandria, Stromata, V, 124, 1. 
of an apologetics. This becomes manifest in the fact that Clement simply overlooks the references to divine immanence. As Herrero explains (2007: p. 292): “a century later, the apologetic urge is less, while the refinement of Christian theology is stronger." ${ }^{1}$ The God of Israel is understood in terms of the promise, whereas the Logos has become obscurely visible to the Orphics, at least according to the form proper of the esthetical epiphanies in the Classical world, which turn apparent as a relative hiddenness: each one illuminates in its own way, but without interacting with each other. For this reason, revelation moves progressively from an imprecise visibility to an increasing clarity through the figure of the archetype, which is characteristic of the Old Testament theology. ${ }^{52}$

The collection of texts adopts thus a distinct proleptic character in which every perception of the divine is simultaneously satisfactory and unsatisfactory, insofar as they aim at an objective beyond that is perceived subjectively. In this sense, the archetypical experience of the Old Testament is in a way, according to the Orphic model, comparable to the immanent beauty.

\section{Conclusion}

In the first part of our paper we have presented a correlation between the archetypical experience in the Old Testament and the worldly beauty in the Orphic model. With respect to the latter, we have proposed as its substance the Clementine notion of a primordial tradition, originated in Egypt, the detritus of which gave rise to the Greek myth. Clement retakes the treatment of the question about faith understood as true gnosis, that is, as discernment of the truth. When we speak of reaching the Father through the Son, this requires believing in the Unknown in order to approach the knowledge of the Unknown.

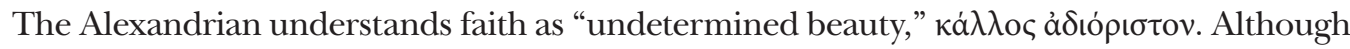
this beauty will not stay for long in his speculation, it will open up the path to beauty as the origin and self-perfection of faith. This leads us to the beginning of speculative theology, which tries to comprehend Biblical revelation and, for this very reason, includes in a systematic manner philosophy and the mythical-literary universe.

If the being manifests the objectivity of the entity, the philosophical action puts the existence at stake. Only from the intimacy of this choice it is possible to reach the knowledge of God that sustains the being. How is this knowledge possible? We might consider the question according to the different levels of human understanding. The first level is the most universal and least clear, although it is accessible to everyone, and it appears

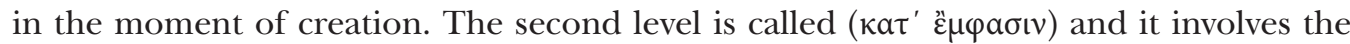
mirrored image, i.e., a knowledge that is achieved by the soul understood as image (and thus as a reflection) of God. It is the form of knowing of those who make an adequate use of reason, for it expresses the strictly philosophical way and is interpreted as a divine gift. The unique Clementine reading of the Orphic texts made possible an intellectual

51 Herrero de Jáuregui (2007: p. 292).

52 Cf. Von Balthasar (1985: pp. 284-285). 
exposition of the experience of faith and offered a justification from the theological point of view. Clement deals with both the evidence of what is believed and the rational foundation of the faith. This philosophical and theological approach is supported on a reflection about the Christian tradition to which Clement belonged and had the goal of engaging in a dialogue with other traditions in order to discover the reasons behind faith.

\section{Bibliography}

Alexandre, M. (Ed.). (1967). Philo of Alexandria: De Congressu Eruditionis Gratia. Paris: Éditions du Cerf.

Allen, Th. W. (Ed.). (1927). Homer: Odysseae (Homeri Opera, Tomes III-IV). Oxford: Oxford Classical Texts.

Aoiz, J. (2012). La evidencia en la filosofía antigua. Azafea: Revista de Filosofía, 14, 165-179.

Arrighetti, G. (Ed.). (1960). Epicurus: Opere (Classici della Filosofia, IV). Turin: G. Einaudi.

Asmis, E. (1999). Epicurean Epistemology. In K. Algra, J. Mansfeld, \& M. Schofield (Eds.), The Cambridge History of Hellenistic Philosophy (pp. 260-294). Cambridge: Cambridge University Press.

Bailly, A. $\left(1963^{3}\right)$. Dictionnaire Grec - Français. Paris: Hachette.

Bernabé, A. (2011). Platón y el orfismo. Diálogos entre religión y filosofía. Madrid: Abda Editores.

Bernabé, A., Casadesús, F., \& Santamaría, M. (Eds.). (2010). Orfeo y el orfismo: nuevas perspectivas. Alicante: Biblioteca Virtual Cervantes [retrieved 03.05.2020 from http://www.cervantesvirtual. com/nd/ark:/59851/bmcm04n6].

Boys-Stones, G. R. (2001). Post-Hellenistic Philosophy: A Study of its Development from the Stoics to Origen. Oxford: Oxford University Press.

Calabrese, C. (2017). Literatura y Teología en el libro X de La Ciudad de Dios. Classica et Christiana, $12,69-88$.

Chambry, E. (Ed.). (1932). Plato: La République (Oeuvres complètes, T. VI-VII). Paris: Société d'Edition 'Les Belles Lettres'.

Dawson, D. (1992). Allegorical Readers and Cultural Revision in Ancient Alexandria. Berkeley - Los Angeles - Oxford: University of California Press.

Diels, H. \& Kranz, W. (1960). Die Fragmente der Vorsokratiker. Berlin: Weidmannsche Verlagsbuchhandlung.

Eliade, M. (1987). The Sacred and the Profane. The Nature of the Religion. New York - London: Harcourt, Inc.

Grabmann, M. (1957). Die Geschichte der scholastischen Methode (Vol. 1). Darmstadt: Wissenschaftliche Buchgesellschaft.

Guardini, R. (1983). Spirito vivente. In Natura, Cultura, Cristianesimo (pp. 93-118). Brescia: Morcelliana.

Hägg, H. F. (2006). Clement of Alexandria and the Beginnings of Christian Apophanticism. Oxford: Oxford University Press.

Hägg, H. F. (2012). Seeking the Face of God: Prayer and Knowledge in Clement of Alexandria. In M. Havrda, et al. (Eds.), The Seventh Book of the Stromateis: Proceedings of the Colloquium on Clement of Alexandria (Olomouc, October 21-23, 2010; pp. 131-142), Leiden - New York: Brill. 
Havrda, M. (2010). Some Observations on Clement of Alexandria, Stromata, Book Five. Vigiliae Christianae, 64, 1-30.

Herren, M. (2017). The Anatomy of Myth. The Art of Interpretation from the Presocratics to the Church Fathers. Oxford: Oxford University Press.

Herrero de Jáuregui, M. (2007). Tradición órfica y cristianismo antiguo. Madrid: Trotta.

Herrero de Jáuregui, M. (2010). Orphism and Christianity in Late Antiquity. Berlin - New York: Walter de Gruyter.

Jourdan, F. (2006). Dionysos dans le Protreptique de Clément d'Alexandrie. Initiations dionysiaques et mystères chrétiens. Revue de l'histoire des religions, 223(3), 265-282.

Jowett, B., \& Pelliccia, H. (Eds.). (1996). Plato: Symposium. New York: Modern Library.

Junco, E. (2018). La sabiduría moral: entre Eurípides y Sócrates. Classica et Christiana, 13, 45-61.

Kern, O. (1922). Orphicorum fragmenta. Berolini: Apud Weidmannos.

Klibengajtis, T. (2004). Die Wahrheitsbezeichnungen des Clemens von Alexandrien in ihrem philosophischen und theologischen Kontext. Vigiliae Christianae, 58(3), 316-331.

Lamberton, R. (1986). Homer the Theologian: Neoplatonist Allegorical Reading and the Growth of the Epic Tradition. Berkeley - Los Angeles - London: University of California Press.

Le Boulluec, A. (Ed.). (1981). Clement de Alexandria: Les Stromates, Stromate V (Tome 1; transl. P. Voulet; Sources chrétiennes, 278). Paris: Éditions du Cerf.

Marrou, H. I. (1985). Historia de la Educación en la Antigüedad. Madrid: Akal Editor.

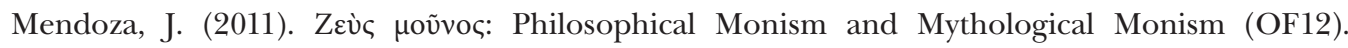
In M. Herrero de Jáuregui, A. I. Jiménez San Cristobal, \& M. A. Santamaría, Tracing Orpheus. Studies of Orphic Fragments (pp. 29-34). Berlin - Boston: Walter de Gruyter.

Merino Rodríguez, M. (Ed.). (2003). Clement de Alexandria: Stromata IV-V (Martirio cristiano e investigación sobre Dios). Madrid, México - Buenos Aires: Ciudad Nueva, 2003.

Merino, M. (2008). Clemente de Alejandría, un filósofo cristiano. Scripta Theologica, 40(3), 803-837.

Most, G. W. (1999). The Poetics of Early Greek Philosophy. In A. L. Long (Ed.), The Cambridge Companion to Early Greek Philosophy (pp. 332-362). Cambridge - New York: Cambridge University Press.

Otto, W. (2003). Los dioses de Grecia. Madrid: Siruela.

Pfeiffer, R. (1968). History of Classical Scholarship from the Beginnings to the End of the Hellenistic Age. Oxford: Clarendon Press.

Reynolds, E. D. (Ed.). (1965). L. Annaei Senecae Ad Lucilium Epistulae Morales. Oxford - New York: Oxford University Press.

Ricoeur, P. (2008). Fe y Filosofía. Problemas del lenguaje religioso. Buenos Aires: Prometeo-UCA.

Rivaud, A. (Ed.). (1925). Plato: Timèe, Critias (Oeuvres complètes, T. X). Paris: Société d'Edition 'Les Belles Lettres'.

Rowe, C. J. (Ed.). (1993). Plato: Phaedo. Cambridge: Cambridge University Press.

Ruíz Aldaz, J. I. (2006). El concepto de Dios en la teología del siglo II. Pamplona: EUNSA.

Sciacca, M. F. (1970). L'oscuramento dell'intelligenza. Milan: Marzorati.

Setaioli, A. (2004). Interpretazioni stoiche ed epicuree in Servio e la tradizione dell'esegesi filosofica del mito e dei poeti a Roma (Comuto, Seneca, Filodemo). International Journal of the Classical Tradition, 11(1), 3-46.

Snell, B. (2010). Die Entdeckung des Geistes. Studien zur Entstehung des europäischen Denkens bei den Griechen. Göttingen: Vandenhoeck \& Ruprecht. 
Snell, B. (Ed.). (19587). Bacchylidis Carmina cum fragmentis (Bibliotheca Teubneriana Scriptorum Graecorum et Romanorum). Leipzig: Teubner.

Struck, P. T. (2004). Birth of the Symbol. Ancient Readers at the Limits of Their Texts. Princeton NJ Oxford: Princeton University Press.

Van den Hoek, A. (1988). Clement of Alexandria and his Use of Philo in the "Stromateis". An Early Christian Reshaping of a Jewish Model. Leiden - New York: Brill.

Von Balthasar, H. U. (1985). Gloria. Una estética religiosa, 1: La percepción de la forma. Madrid: Ediciones Encuentro.

West, M. L. (Ed.). $(1997$ = 1966). Hesiod: Theogony. Oxford - New York: Clarendon Press.

Wyrwa, D. (1983). Die christliche Platonaneignung in den "Stromateis" des Clemens von Alexandrien. Berlin - New York: De Gruyter.

Claudio Calabrese / ccalabrese@up.edu.mx

Department of Humanities

Panamerican University

Av. Josemaría Escrivá de Balaguer 101, 20296 Aguascalientes, México

Nassim Bravo / fbravo@up.edu.mx

Department of Humanities

Panamerican University

Av. Josemaría Escrivá de Balaguer 101, 20296 Aguascalientes, México 